\title{
Penguatan Ekonomi Masyarakat Nelayan dalam Mempertahankan Kelangsungan Hidup melalui Pendekatan Deverifikasi Produk Hasil Tangkap Ikan di Kabupaten Cilacap
}

\author{
Kristian Cahyandi \\ Akademi Maritim Nusantara, Cilacap \\ andykrist94@gmail.com
}

Diterima 12 Agustus 2021, direvisi 27 Agustus 2021, diterbitkan 06 Oktober 2021

\begin{abstract}
Abstrak
Meneliti dinamika masyarakat nelayan akan dihadapkan pada persoalan yang komplek, sehingga perlu mendapatkan perhatian yang serius dan berkesinambungan. Untuk mewujudkan ketepat sasaran dalam pola pembangunan masyarakat nelayan, tidak dapat begitu saja mengesampingkan berbagai sifat dan karakter yang melekat didalamnya. Pada saat mendekati komunitas antara masyarakat nelayan juga berbeda dengan pada saat mendekati masyarakat petani. Di samping lokasi kegiatan yang berbeda, tipikal sosiologi masingmasing komunitas masyarakat tersebut juga berbeda, sehingga dalam menentukan pola pembangunan antara dua kounitas masyarakat tersebut menjadi berbeda. Tujuan penelitian untuk menawarkan solusi aplikatif terhadap upaya peguatan ekonomi masyarakat nelayan melalui deverifikasi produk hasil tangkap ikan. Kendala yang menjadikan betapa susahnya untuk mengentaskan kemiskinan dan meningkatkan kesejahteraan pada komunias masyarakat nelayan adalah dipengaruhi oleh faktor internal maupun eksternal dari masyarakat nelayan itu sendiri. Faktor internal yang melekat pada masyarakat nelayan, dari mulai tingkat pendidikan, permodalan, hingga penggunaan dalam teknologi tangkap ikan. Sedangkan dari factor eksternal dapat dilihat dari potensi sumber daya alam laut yang semakin berkurang, tingkat persingan yang semakin tinggi pada kalangan masyarakat nelayan pemilik modal, pengolahan bahan mentah hingga mekanisme pasar yang dihadapi masyarakat desa pesisir. Metode yang digunakan dalam penelitian ini menggunakan pendekatan deskriptif kualitatif yang bersumber dari olahan data primer dan sekunder. Hasil dari penelitian memberikan gambaran mengenai diperlukannya suatu terobosan baru dalam upaya pengentasan kemiskinan melalui peguatan ekonomi pada komunitas masyarakat nelayan, dari yang sebelumnya bertitik tumpu pada orientasi kuantitas hasil berubah menjadi upaya pengembangan hasil atau deversifikasi usaha. Diiringi dengan peningkatan kemandirian masyarakat desa pesisir.
\end{abstract}

Kata kunci : Penguatan Ekonomi, Tangkap Ikan, Deversifikasi Produk, Nelayan, Kemiskinan

\begin{abstract}
Researching the dynamics of fishing communities will be faced with complex problems, so it needs to get serious and continuous attention. To realize the determination of the target in the pattern of development of fishing communities, it cannot simply rule out the various traits and characters inherent in it. When approaching the community between fishing communities is also different from when approaching the farming community. In addition to different locations of activities, the typical sociology of each community of the community is also different, so that in determining the pattern of development between the two community communities becomes different. The purpose of the study is to offer an applicative solution to the economic efforts of fishing communities through the deverification of fishing products. The obstacles that make it difficult to alleviate poverty and improve welfare in the communique of the fishing community are influenced by internal and external factors of the fishing community itself. Internal factors attached to fishing communities, ranging from education level, capital, to use in fishing technology. While from external factors can be seen from the potential of marine natural resources that are decreasing, the level of increasing pressure among the fishing community of capital owners, processing raw materials to market
\end{abstract}


mechanisms faced by coastal village communities. The methods used in this study use qualitative descriptive approaches derived from primary and secondary data processing. The results of the study provide an overview of the need for a new breakthrough in poverty alleviation efforts through economic support in fishing communities, from previously tumpu on the orientation of quantity of results turned into efforts to develop results or deversification of businesses. Accompanied by increased independence of coastal village communities

Keywords : : Economic Development, Fishing, Product Deversification, Fishermen, Poverty

\section{Pendahuluan}

Penelitian ini mengkaji tentang upaya penguatan ekonomi masyarakat nelayan dalam mempertahankan kelangsungan hidupnya melalui deverifikasi produk hasil tangkap ikan. Yang dimaksud dengan deverifikasi produk disini adalah bentuk upaya untuk menganekaragamkan olahan hasil tangkap ikan nelayan. Gambaran tentang masyarakat nelayan pesisir telah terbentuk bahwa masyarakat nelayan identik dengan kemiskinan dan keterbelakangan. Namun pada beberapa desa nelayan baik itu dalam lingkup Kabupaten Cilacap maupun diluar wilayah, ditemukan pada beberapa desa nelayan adanya kemajuankemajuan yang tergambar dalam bentuk perkembangan pembangunan, baik itu berupa infrastruktur sarana ibadah ataupun sekolah yang megah maupun fasilitas-fasilitas public yang memadai. Sehingga dapat dikatakan bahwa sebenarnya masyarakat nelayan dapat dan mampu untuk melakukan kemajuan. Kusnaidi (2009) menyatakan bahwa kerap kali masyarakat nelayan diragukan kemampannya apabila bekerja di darat. Keberadaan nelayan seringkali hanya diidentikan dengan pekerjaan diatas laut, yang sebenarnya pekerjaan tersebut tidak semua masyarakat umum bisa melakukakannya. Namun dengan keterampilan dan spesifikasi unik pekerjaan nelayan tersebutpun belum mampu untuk memberikan posisi yang terhormat di lapisan masyarakat.

Banyaknya komunitas masyarakat nelayan yang timbul di pesisir pantai memiliki keterkaitan dengan keberadaan potensi sumber daya alam pada perairan laut tersebut. Potensi sumber daya alam berupa ekosistem laut menjadi komoditas yang banyak dicari oleh masyarakat dari berbagai daerah dan wilayah. Kemampuan dalam memanfaatkan potensi kelautan tersebut semakin lama semakin meningkat seiring dengan peningkatan keterampilan dan kemampuan pelaku yang bekerja pada sektor tangkap ikan laut. Disisi lain, pihak regulator atau pemerintah masih dirasa kurang keberpihakannya dalam menggerakkan maupun memajukan pembangunan wilayah pada desa pesisir, dimana masih belum terpadu dan terkonektifitas antar sector pada pemerintahan pusat dengan daerah. Sehingga sudah waktunya pemerintah melakukan evaluasi terhadap program kerjanya. Dengan lebih memfokuskan pada pembangunan desa-desa pesisir salah satunya melalui deverifikasi produk tangkap ikan. Berdasarkan gambaran kondisi kehidupan ekonomi dan social masyarakat nelayan pesisir yang telah disampaikan diatas, maka perlu suatu kajian yang diharapkan dapat memberikan solusi melalui pertanyaan bagaimana mempertahankan kelangsungan hidup masyarakat pesisir laut melalui pedekatan deverifikasi produk hasil tangkap ikan di Kabupaten Cilacap?

\section{Materi dan Metode}

Hal utama dapat dilihat dari kondisi kemiskinan dan kesenjangan social ekonomi dalam kehidupan masyarakat pesisir nelayan adalah adanya gabaran yang tampak mata berupa kualitas pemukiman tinggal. Desa- desa pada masyarakat nelayan miskin mudah diidentifikasi dari kondisi rumah hunian mereka. Rumahrumah yang sangat sederhana, berdinding anyaman bambu, berlantai tanah berpasir, beratap daun rumbia, dan keterbatasan pemilikan perabotan rumahtangga adalah tempat tinggal para nelayan buruh atau nelayan tradisional. Sebaliknya, rumah hunian yang megah dengan segala fasilitas yang memadai akan mudah dikenali sebagai tempat tinggal pemilik perahu, pedagang perantara atau pedagang berskala besar dan pemilik toko (Kusnadi 2002).

Fisheries Improvement Projects And Small Scale fisheries: The Need For a Modified Approach (2019). Dalam tulisan proyek peningkatan perikanan dan perikanan skala kecil ini menyampaikan bahwa menunjukkan 
rangkaian yang lebih luas dari intervensi pemerintah yang dihadapkan kompleksitas sosial dan perencanaan ekonomi yang melekat dalam dengan sekedar meningkatkan pendapatan nelayan saja. Untuk menjadi rumusan model yang sukses perlu mempertimbangkan investasi dalam hal-hal berikut: memperkuat kepemilikan dan tata kelola masyarakat; menutupi biaya peluang di muka; mengurangi kerentanan nelayan guncangan pasar dengan mendukung portofolio mata pencaharian yang lebih luas; dan mengurangi kredit, kendala sosial dan manusia dalam konteks yang lebih luas. Selain itu seharusnya melakukannya dengan cara yang bergantung pada peningkatan manajemen perikanan.

The Livelihoods Approach and Management of Small Scale Fisheries (2001). Pendekatan Mata Pencaharian dan Manajemen Perikanan Skala Kecil. Pendekatan untuk pengurangan kemiskinan di negara-negara berpenghasilan rendah yang dikenal sebagai "pendekatan mata pencaharian berkelanjutan" diterapkan memahami strategi nelayan menghadapi dan mengelola sumber daya perikanan yang berfluktuasi. Pendekatan mata pencaharian adalah dijelaskan, dan wawasan yang diberikannya ke dalam kebijakan pengelolaan perikanan konvensional di negara berkembang dieksplorasi. Ini berpendapat bahwa baik manajemen yang dipimpin negara dan beberapa pendekatan hak guna masyarakat atau teritorial yang lebih baru, jika didasarkan pada pemahaman yang tidak lengkap tentang mata pencaharian, dapat mengakibatkan arahan pengelolaan tidak sesuai dengan konservasi sumber daya dan tujuan sosial dan ekonomi manajemen.

Diversifikasi terjadi sebagai bagian dari dilakukannya pengembangan produk, dimana produk lama secara ekonomis masih dapat dipertahankan. Suatu pengembangan produk merupakan aktivitas yang dilakukan dalam menghadapi prediksi adanya perubahan produk kearah yang lebih baik, sehingga dapat meningkatkan daya pemuas dan daya tarik yang lebih besar, dengan harapan memperoleh keuntungan yang lebih besar (Sofjan 2009).

Jenis penelitian yang digunakan adalah penelitian deskriptif kualitatif. Penelitian ini mengungkapkan fakta yang ada dan melalui interprestasi yang dilakukan, Penelitian menggunakan data primer dan sekunder. Data primer diperoleh langsung dari 35 responden anggota HNSI Kabupaten Cilacap melalui observasi dan wawancara. Sedang data sekunder diperoleh dari dokumen pemerintahan desa, dokumen HNSI Kabupaten Cilacap, Dinas Perikanan Kabupaten Cilacap dan juga dari berbagai bahan bacaan

Analisis data yang digunakan dalam penelitian ini adalah analisis deskriptif. Menurut Bogdan dan White (dalam Moleong, 1989) penelitian deskriptif adalah metode penelitian yang menghasilkan data deskriptif berupa katakata tertulis atau lisan dari orang-orang dan perilaku yang diamati. Tujuan dari penelitian deskriptif adalah untuk membuat deskripsi, gambaran atau lukisan secara sistematis, faktual dan akurat mengenai fakta-fakta, sifat-sifat serta hubungan antar fenomena yang diselidiki.

\section{Hasil dan Pembahasan}

Permasalahan yang kerap mengemuka dalam usaha menciptakan aktifitas perikanan yang berkelanjutan di Kabupaten Cilacap adalah pengelolaan komoditas perikanan (fisheries management) dari pelaku usaha perikanan. Sistem pengelolaan perikanan yang masih lemah merupakan permasalahan umum yang utama dalam mewujudkan sektor perikanan berkelanjutan. Kondisi tersebut ditunjukkan dengan ketidak merataannya pemanfaatan sumber daya alam pada sector perikanan di Kabupaten Cilacap, dimana pada wilayah barat tingkat penangkapannya sudah overfishing, sementara pada wilayah timur masih underfishing.

Jumlah Kecamatan yang berada di wilayah Kabupaten Cilacap sebanyak 24 Kecamatan, Produksi perikanan tangkap di Kabupaten Cilacap secara jumlah tangkapan paling banyak pada Kecamatan Cilacap Selatan. Posisi kedua pada Kecamatan Kesugihan, dan posisi ketiga di Kecamatan Nusawungu. Hasil tangkap ikan di Kecamatan Cilacap selatan adalah yang terbanyak karena Kelurahan Cilacap yang merupakan salah satu bagian dari wilayah Kecamatan Cilacap Selatan dengan luas wilayah kelurahan Cilacap sebesar 171,364 hektar, terdiri dari 18 Rukun Warga (RW) dan 93 Rukun Tetangga (RT) memiliki batas wilayah sebelah Selatan dengan Selat Nusakambangan, dan sebelah Timur dengan Samudera Indonesia. 
Tabel.1 Produksi Perikanan Tangkap Menurut Kecamatan dan Subsektor (Kg), 2020

\begin{tabular}{|c|c|c|c|c|}
\hline Kecamatan & $\begin{array}{l}\text { Perairan } \\
\text { Laut }\end{array}$ & Sungai & Rawa & $\begin{array}{c}\text { Genangan } \\
\text { Lainnya }\end{array}$ \\
\hline Dayeuhluhur & - & 15363.0 & - & - \\
\hline Wanareja & - & 14748.5 & 12722.0 & 10339.2 \\
\hline Majenang & - & 5194.8 & 2710.4 & - \\
\hline Cimanggu & - & 2522.1 & 1669.9 & - \\
\hline Karangpucung & - & 2774.3 & - & 5405.6 \\
\hline Cipari & - & 7233.1 & 3926.1 & - \\
\hline Sidareja & - & 35583.7 & 3482.1 & 3027.4 \\
\hline Kedungreja & - & 232008.6 & 60308.7 & 41006.0 \\
\hline Patimuan & - & 107617.0 & 32717 & 29864.7 \\
\hline Gandrungmangu & - & 3095.6 & - & 23862.2 \\
\hline Bantarsari & - & 20716.2 & 65892.1 & 15620.6 \\
\hline Kawunganten & - & 58590.8 & - & 84275.3 \\
\hline Kampung Laut & 406567.6 & - & - & - \\
\hline Jeruklegi & - & 33403.0 & - & 18319.4 \\
\hline Kesugihan & 797591.8 & 2715.4 & 90347.0 & 10333.1 \\
\hline Adipala & 105772.7 & 4576.2 & 55661.8 & 3240.3 \\
\hline Maos & - & 71855.8 & - & 4461.8 \\
\hline Sampang & - & 12264.7 & - & 6856.9 \\
\hline Kroya & - & 11017.7 & 34821.3 & 32846.5 \\
\hline Binangun & 10293.7 & 736.2 & - & 5205.0 \\
\hline Nusawungu & 608006.5 & 2768.1 & - & 2458.2 \\
\hline Cilacap Selatan & 22671311.0 & - & - & - \\
\hline Cilacap Tengah & 191916.7 & - & - & - \\
\hline Cilacap Utara & 453624.6 & 10447.8 & 25331.1 & - \\
\hline CILACAP & 25245084.6 & 655232.7 & 389589.5 & 297082.3 \\
\hline
\end{tabular}

Sumber : Dinas Perikanan Kab Cilacap, Tahun 2021

Pada wilayah penangkapan ikan tertentu yang menunjukkan adanya over-exploitation, nelayan pada daerah tersebut umumnya adalah miskin, disebabkan faktor sulitnya mendapatkan ikan hasil tangkapan. Selain itu, sangat rawan timbulnya konflik antar nelayan di perairan tersebut. Disisi lain, pada wilayah penangkapan ikan yang pemanfaatannya belum optimal atau underfishing, sumber daya ikan yang tersedia seolah terabaikan begitu saja. Kenyataan yang terjadi tersebut sebagai gambaran betapa belum mapannya pengelolaan perikanan daerah, sehingga pemerintah daerah perlu melakukan penataan dan memperbaiki kelemahan yang ada dengan melakukan evaluasi dan penguatan kebijakan, dengan harapan dapat berdampak pada penguatan gambaran perekonoian masyarakat nelayan dalam bentuk peningkatan pendidikan dan tempat tinggal yang lebih baik.

Permasalahan lainnya yaitu pada pelaku usaha perikanan yang sebagian besar belum memiliki pengetahuan dan keterampilan yang memadahi berkaitan dengan usaha perikanan yang berkelanjutan, serta belum memiliki skala usaha yang layak (economy of scale). Yang terjadi akibatnya, cukup banyak masyarakat nelayan yang melakukan kegiatan usaha perikanan yang tidak berkelanjutan, bahkan masih ada yang menggunakan sarana tangkap atau bahan-bahan yang berbahaya bagi sumber daya alam perikanan, lingkungan, dan manusia. Apalagi dengan skala usaha ekonomi mereka yang relative kecil, mengakibatkan para pelaku usaha sector perikanan tersebut cenderung lebih mengejar kuantitas produksi, tanpa memperhatikan ekosistem pendukungnya.

Pada situasi pasar, produk perikanan masih kalah bersaing dibanding dengan produk pangan lainnya, seperti daging sapi dan ayam. Permasalahan pada usaha sector perikanan yang belum efisien serta rutinitas produksi yang tidak stabil. Hal tersebut terjadi dikarenakan kurangnya sarana prasarana maupun pengetahuan yang cukup untuk dapat meningkatkan atau memberikan value added pada produk perikanan.

Permasalahan tersebut juga ditambah dengan tidak mudahnya prosedur pengajuan kredit perbankan bagi masyarakat nelayan pada skala kecil. Suku bunga kredit yang relatif tinggi juga turut menjadi salah satu factor penghambat tumbuh kembangnya usaha perikanan yang digarap oleh nelayan. Pegaruh yang timbul dengan sulitnya akses permodalan usaha bagi nelayan menjadikan usaha perikanan tangkap cenderung diam ditempat. Terbatasnya akses permodalan bagi nelayan juga menjadi penyebab salah satu pemanfaatan sumberdaya ikan yang tidak merata di beberapa wilayah

Untuk menambah pengetahuan dan keterampilan masyarakat nelayan serta mengupayakan inovasi pada usaha tangkap ikan dan dapat menambah penghasilan rumah tangga, maka perlu usaha pengenalan deverifikasi produk hasil tangkap ikan dalam bentuk penganekaragaman olahan hasil tangkap ikan nelayan. Komoditas perikanan merupakan bentuk barang yang dapat cepat mengalami kerusakan karena tidak tahan disimpan terlalu lama untuk dapat menjaga tingkat kesegarannya. Dengan deverifikasi produk tangkap ikan akan memberikan solusi dalam 
meminimalkan tingkat kerusakan produk perikanan dengan melakukan upaya pengolahan yang menjadikan komoditas ikan menjadi lebih tahan lama namun tetap bernilai ekonomis dengan daya jual yang tinggi dan stabil.

Melalui deverifikasi hasil tangkap ikan berupa penganekaragaman olahan, produk perikanan diharapkan mampu bertahan lebih lama dengan nilai jual yang relatif stabil. Bahkan dapat memberikan nilai tambah dari harga jual ikan mentah, karena dapat memberiakan variasi bentuk olahan yang dittawarkan kepada konsumen. Deversifikasi juga merupakan salah satu upaya untuk meningkatkan daya serap pasar, dimana inovasi olahan baik melalui system pengalengan maupun pengasinan dapat meningkatkan permintaan serta menciptakan alternatif pengembangan usaha bagi pekerja pada sektor tangkap ikan.

Pendidikan bagi nelayan pada prisipnya merupakan human investmen dan social capital, baik untuk kepentingan pembangunan daerah secara khusus maupun pembangunan nasional secara umum. Pendidikan yang merata dan berkualitas baik melalui pendidikan formal maupun non formal akan memberikan peningkatan kecerdasan dan kesejahteraan nelayan. Dengan pendidikan yang memadai, dapat dijadikan sebagai modal untuk mengembangkan hasil tangkap ikan yang diperoleh. Terjadinya kemiskinan nelayan tidak hanya disebabkan masalah ekonomi akan tetapi salah satu penyebabnya adalah pengetahuan dan pendidikan yang rendah. Pemerintah harus memperhatikan dan engupayakan regenerasi pada masyarakat nelayan, sehingga nelayan dapat lebih kompetitif dan mampu memanfaatkan sumberdaya alam dengan lebih baik dan bijak di masa depan. Karena pada hakekatnya potensi sumber daya perikanan laut dapat dijadikan sebagai kekuatan untuk mensejahterahkan nelayan, keluarga dan lingkungannya, serta menjadi landasan utama dalam pembangunan masyarakat desa pesisir kedepan.

Berkaitan dengan konflik, dari sisi pemanfaatan sumber daya ikan, nelayan tradisional kerap kali menghadapi ketidakadilan dalam pemanfaatan sumberdaya ikan diakibatkan karena perbedaan penguasaan pada modal dan kapital. Sebagai contoh, konflik yang terjadi karena beroperasinya kapal trawl pada perairan pesisir yang sebenarnya merupakan wilayah penangkapan nelayan tradisional. Dalam analisis terdapat tiga macam konflik nelayan berdasar dari faktor penyebabnya. Pertama, yang disebut dengan konflik kelas, merupakan konflik yang terjadi antar kelas sosial nelayan dalam memperebutkan wilayah penangkapan (fishing ground).

Kedua, adanya konflik orientasi, yaitu konflik yang terjadi antar nelayan yang memiliki perbedaan sudut pandang dalam memanfaatkan potensi sumberdaya, yaitu antara nelayan yang memiliki kepedulian terhadap pemanfaatan sumberdaya yang ramah lingkungan (orientasi jangka panjang) dengan nelayan yang dalam melakukan kegiatan pemanfaatan mengabaikan bahkan cenderung merusak lingkungan, seperti penggunaan bahan peledak, racun, listrik dan lain sebagainya (orientasi jangka pendek).

Ketiga, adalah konflik agraria, merupakan konflik yang timbul dikarenakan perebutan wilayah penangkapan ikan, yang bisa terjadi antar kelompok nelayan. Dapat juga terjadi antara nelayan dengan pihak diluar nelayan, seperti antara nelayan dengan pelaku usaha lain, seperti transportasi laut, wisata maupun pertambangan.

Dengan adanya kompleksitas permasalahan pada masyarakat nelayan perlu adanya penanganan yang melihat permasalahan dari sudut pandang yang luas. Kerap kali solusi yang dinggap tepat adalah menaikkan kuantitas dari hasil tangkap ikan nelayan, namun hal tersebut menjadi kurang menyentuh orientasi jangka panjang, yaitu kebutuhan adanya investasi bagi masa depan. Dengan demikian maka model pembangunan dan pemberdayaan perlu untuk mengubah paradigma, program pemberdayaan masyarakat nelayan di Kabupaten Cilacap yang semula cenderung berorientasi pada kuantitas hasil produksi ke pola baru dengan berorientasi pada efisiensi proses produksi dan upaya pengembangan deversifikasi produk hasil tangkap ikan 


\section{Kesimpulan}

Kontribusi yang dilakukan oleh kegiatan deversifikasi terhadap pendapatan nelayan dapat bervariasi. Salah satunya deversifikasi hasil tangkap ikan yang dilakukan pada berbagi macam bentuk olahan pada ikan segar hasil tangkapan melalui system pengalengan maupun pengasinan. Pada tahap ini nelayan ini tidak lagi menerima pendapatan dari pedagang grosir atau pengolah pihak ketiga. Namun kenyataannya kegiatan tersebut dilakukan tidak konstan sepanjang tahun, tetapi bervariasi menurut musim, terlebih pada musim paceklik. Karena nelayan masih meminati untuk menjual hasil tangkapan mereka secara langsung. Deversifikasi merupakan strategi yang efektif dalam berkontribusi pada mata pencaharian nelayan pada berbagai situasi yang berbeda. Kontribusi potensial deverifikasi terhadap keberlanjutan dan kelangsungan hidup masyarakat nelayan dipengaruhi oleh factor internal dan eksternal. Faktor lain yang ikut mendukung keberhasilan dalam program deverifikasi adalah adanya sikap dan keyakinan nelayan, partisipasi anggota keluarga, kekuatan pasar, dan geografis. Selanjutnya, nelayan harus memiliki pengalaman, keterampilan, dan modal yang diperlukan. Pada situasi di mana terdapat permintaan hasil produk deversifikasi olahan hasil tangkap ikan, nelayan mungkin akan menghadapi berbagai hambatan peraturan yang mungkis bisa membatasi perkembangan usaha. Sehingga pemerintah daerah pada khususnya perlu memberikan dukungan dalam bentuk system terhadap nilai tambah produk yang akan didistribusikan pada pasar local maupun global.

\section{Ucapan terima kasih}

Penulis mengucapkan terima kasih kepada Akademi Maritim Nusantara-Cilacap dalam mendukung dan memfasilitasi baik secara finansial maupun moril pada penelitian ini. Penulis juga menyampaikan terimakasih kepada kolega program studi atas dikusinya yang bermanfaat.

\section{Daftar Pustaka}

[1] Badan Pusat Statitistik (BPS), 2019, Kabupaten Cilacap Dalam Angka, BPS, Cilacap
[2] Dinas Perikanan dan Kelautan [DKP]. 2021. Perikanan dan Kelautan dalam Angka 2021: Dinas Perikanan dan Kelautan Kabupaten Cilacap

[3] Himpunan Nelayan Seluruh Indonesia (HNSI), 2018, Laporan Tahunan HNSI DPC Cilacap Tahun 2018, HNSI, Cilacap

[4] Kusnadi, (2009), Keberdayaan Nelayan dan Dinamika Ekonomi Pesisir, Pusat Penelitian Wilayah Pesisir dan Pulau-Pulau Kecil Univ. Jember bekerjasama Ar-Ruzz Media, Yogyakarta

[5] Masyhuri, 2001. Adaptasi Kelembagaan Ekonomi Masyarakat Nelayan dalam Pemanfaatan Sumberdaya Alam Indonesia. Pusat Penelitian Ekonomi Lembaga Ilmu Pengetahuan Indonesia (P2E - LIPI); Jakarta.

[6] Mubyarto, Loekman Soetrisno, Michael Dove.1984. Nelayan dan Kemiskinan. Jakarta:Rajawali Press.

[7] N. Gregory Mankiw, 2006, Mikro Ekonomi, Erlangga, Jakarta

[8] Raharjo, Priyanto. 2000. Nelayan Nusantara Sebuah Falsafah Kehidupan. Makalah Falsafah Sains. Program Pascasarjana, IPB.

[9] Rhona Barra, Aaron Brunerb, Scott Edwardsb, (2019). Fisheries Improvement Projects and small-scale fisheries: The need for a modified approach

[10] R. Bintarto. 1977. Geografi Desa. Yogyakarta: UP. Spring.

[11] Satria. 2002. Pengantar Sosiologi Masyarakat Pesisir. Cidesindo, Jakarta

[12] Soekamto, Soerjono, 1990. Sosiologi Suatu Pengantar. Jakarta: Rajawali Press

[13] Sofjan Assauri, Manajemen Pemasaran. (Jakarta : PT Grafindo Persada, 2009), Cet. Ke-10 h.218

[14] Suyanto, Bagong. 2003. Mencari Model Pemberdayaan Komunitas Desa Pantai. Surya,10 September 2003 